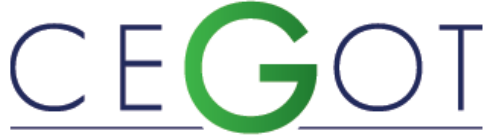

Centro de Estudos de Geografia e Ordenamento do Território
Geografia e Ordenamento do Território, Revista Eletrónica Centro de Estudos de Geografia e Ordenamento do Território http://cegot.org ISSN: 2182-1267

\author{
ALVES, JESSICA \\ Mestra em Geografia pela Universidade do Estado do Rio Grande do \\ Norte - UERN \\ 59604-430, Mossoró, Rio Grande do Norte, Brasil \\ jessica_jessiana@hotmail.com
}

\author{
Medeiros, Wendson \\ Professor Adjunto do Departamento de Gestão Ambiental e do \\ Mestrado em Geografia da Universidade do Estado do Rio Grande do \\ Norte - UERN \\ Mossoró, Rio Grande do Norte, Brasil \\ wendsonmedeiros@uern.br
}

\title{
Inventariação do património geomorfológico cárstico do Parque Nacional da Furna Feia (RN, Brasil) como proposta para uso geoturístico
}

\author{
Inventory of the karst geomorphological heritage of the Furna Feia National Park (RN, Brazil) as a proposal \\ for geotouristic use
}

Referência: Alves, Jessica; Medeiros, Wendson (2020). Inventariação do património geomorfológico cárstico do Parque Nacional da Furna Feia (RN, Brasil) como proposta para uso geoturístico. Revista de Geografia e Ordenamento do Território (GOT), no 20 (Dezembro). Centro de Estudos de Geografia e Ordenamento do Território, p. 122-148, dx.doi.org/10.17127/got/2020.20.006

\section{RESUMO}

As formas de relevo que possuem valor patrimonial, constituintes do geopatrimónio e, em específico, do Património Geomorfológico, detêm um conjunto de valores no qual se destacam o aspeto científico e o apelo cênico, tornando-as atrativas para o desenvolvimento da atividade geoturística quando há a motivação de não apenas visitar mas de conhecer as origens e modos de evolução da formação geomorfológica visitada. Com uma grande variedade de formas do relevo que estão relacionados à paisagem cárstica, o Parque Nacional da Furna Feia possui um elevado potencial para o desenvolvimento do geoturismo pela presença de feições exocársticas e endocársticas, significativas em âmbito local e regional. Diante disso, o trabalho teve como objetivo inventariar o património geomorfológico cárstico do Parque Nacional da Furna Feia como proposta para o uso geoturístico. A partir do processo de inventariação, foi possível identificar quatro Geomorfossítios de alto potencial, que integram um património geomorfológico cárstico de grande relevância para o desenvolvimento do geoturismo, que poderão vir a fortalecer estratégias de geoconservação e subsidiar o desenvolvimento local 
sustentável mediante a inclusão e participação das comunidades locais, além de proporcionar a popularização dos conceitos relacionados à conservação da geodiversidade.

Palavras chave: Geopatrimónio; Unidade de Conservação; Carste; Geoturismo.

\section{ABSTRACT}

The landforms that have patrimonial value, constituting geoheritage and, in particular, Geomorphological heritage, hold a set of values in which the scientific aspect and scenic appeal stand out, which make them attractive for the development of geotouristic activity, when there is the motivation to not only visit, but to know the origins and modes of evolution of the geomorphological formation visited. With a wide variety of landforms that are related to the karst landscape, the Furna Feia National Park has a high potential for the development of geotourism, due to the presence of significant exokarst and endokarst features at the local and regional level. Therefore, the work aimed to inventory the karst geomorphological heritage of the Furna Feia National Park as a proposal for geotouristic use. From the inventory process, it was possible to identify four high potential geomorphosites that integrate a karst geomorphological heritage of great relevance for the development of geotourism, which in turn, from it's development, may strengthen geoconservation strategies and subsidize sustainable local development, through the inclusion and participation of local communities, in addition to promoting the popularization of concepts related to the conservation of geodiversity.

Keywords: Geoheritage; Protected Area; Karst; Geotourism.

\section{Introdução}

As formas de relevo fazem parte do conjunto de elementos que englobam a geodiversidade em seu sentido restrito, que considera apenas a vertente abiótica da diversidade natural. A conservação dessas formas faz parte das discussões recentes que envolvem a temática e que tem como primordial questão, pensar possibilidades de uso destas feições mediante atividades de base sustentável, de modo a possibilitar uma maior visibilidade em relação à sua importância para a geoconservação, enquanto elementos que fazem parte de um sistema que integra a paisagem (Gray, 2004; Reynard, 2005).

Essa questão consiste em um desafio e em um debate que ainda precisa ser fortalecido, pois apesar das formas de relevo serem atrativos turísticos em áreas naturais no Brasil, principalmente em razão de seu valor cênico e paisagístico, são quase inexistentes as ações voltadas para a disseminação da importância destes elementos como significativos do ponto de vista científico/educativo. 
Possuindo estas características, as formas do ambiente cárstico entram neste debate como elementos significativos da paisagem, por demonstrarem aspetos que justificam a importância de serem conservados, pois representam ambientes complexos de interrelação entre superfície e subsuperfície, mediante a ação de um agente-chave que é a água. $A$ paisagem cárstica pode apresentar aspetos cênicos, ecológicos, climáticos, paleontológicos, arqueológicos e geomorfológicos que se traduzem em valores que fundamentam a importância de serem inseridos em estratégias educativas de conscientização.

Estes valores são esclarecidos pela presença de elementos, formas e processos significativos que permitem contar a história geoevolutiva de uma região, bem como podem se constituir como base para o desenvolvimento de formas únicas de vida e, em alguns casos, possuir aspeto cênico e potencial científico/educativo relevante para o desenvolvimento de atividades de lazer e recreação que envolvam a transmissão de conhecimento sobre a formação visitada, como o geoturismo.

Diante disso, estas formas e processos, enquanto elementos da geodiversidade, passam a ter um valor patrimonial do ponto de vista geomorfológico, sendo vistos como monumentos naturais em virtude da necessidade de conservação. Esta necessidade parte da premissa de que o consumo e destruição de formas abióticas são perdas irreversíveis, pois, uma vez deterioradas, não podem retornar ao seu estado inicial. Seria como se uma página importante do livro que conta a história geoevolutiva do local e região fosse totalmente arrancada e perdida. Dessa forma, estratégias de valorização das formas abióticas que envolvem as formas de relevo são emergentes, em especial na paisagem cárstica, tendo como intuito a aproximação da sociedade com a diversidade de formas abióticas que a circundam (Santos, Cravidão \& Cunha, 2010).

Dessa forma, as unidades de conservação e, em especial, os parques nacionais tornam-se importantes meios de possibilitar esta aproximação, pois possuem seus objetivos alicerçados na conservação do ambiente natural através da promoção de atividades educativas e turísticas, seguindo os princípios da sustentabilidade (Brasil, 2000).

É nesta perspetiva que o Parque Nacional da Furna Feia (Parna Furna Feia) é aqui discutido, pois possui o propósito de conservar um significativo património geomorfológico cárstico que sustenta um representativo remanescente do bioma Caatinga, além de possuir 
objetivos voltados para o desenvolvimento de atividades de educação e interpretação ambiental. Criado pelo Decreto s/n de 5 de junho de 2012 (Brasil, 2012) o Parna apresenta uma vasta quantidade de formas do relevo cárstico em superfície e em subsuperfície que, além de possuírem grande representatividade da evolução geomorfológica da região, apresentam características significativas para o desenvolvimento da atividade geoturística. Nesse contexto, o presente trabalho objetiva inventariar o património geomorfológico cárstico da área do Parque Nacional da Furna Feia, com foco no desenvolvimento do geoturismo.

\section{Breve discussão sobre os conceitos de Geodiversidade, Património Geomorfológico Cárstico e Geoturismo}

O termo geodiversidade foi criado pelo geógrafo argentino Frederico Alberto Daus, na década de 1940, que usava o termo como sinônimo de diversidade geográfica de lugares, ou seja, em uma perspetiva muito abrangente (Medeiros \& Oliveira, 2011). Com um sentido mais restrito, novos conceitos de geodiversidade foram criados e discutidos a partir da década de 1990, o que foi muito bem aceito pela comunidade acadêmica. Nesta perspetiva, o conceito de geodiversidade passa a abarcar, de modo mais ou menos consensual, somente os elementos abióticos que compõem o planeta Terra, envolvendo os elementos geológicos, geomorfológicos, pedológicos, hidrológicos e climatológicos que dão origem e transformam as paisagens (Gray, 2004; Medeiros \& Oliveira, 2011).

Alguns elementos da geodiversidade se caracterizam por serem de grande relevância, isto por possuir características superlativas do ponto de vista científico, cênico, educativo, cultural ou outro, pelo que necessitam de proteção e conservação. Assim, parte da geodiversidade pode ser considerada como geopatrimónio, onde se destaca o Património Geomorfológico, que é emergente, uma vez que possui um caráter irrecuperável por se constituir a base para o desenvolvimento de todas as atividades antrópicas. Este património é considerado por uma parcela de formas do relevo que apresenta um conjunto de valores, podendo ser científico, estético, cultural, ecológico e/ou econômico, que reforçam a necessidade de conservação, valorização e utilização em atividades de lazer, desporto e turismo com base nos princípios da sustentabilidade (Vieira, 2014). 
Os locais de relevante interesse que compõem o Património Geomorfológico são os Geomorfossítios, que podem apresentar diversos tipos de valores e em especial a relevância científica/educativa e estética, importante para o desenvolvimento do segmento do turismo que tem por base o geopatrimónio, sendo este o geoturismo (Panizza, 2001). A atividade geoturística, segundo Moura-Fé et al. (2017, p.3055), trata-se de uma

atividade turística com conotação geocientífica, que propõe a visita organizada e orientada a locais que testemunham uma fase do passado ou da história de origem e evolução do planeta, que se notabilizam como uma herança coletiva e que devem ser preservados para as gerações futuras.

Esta atividade pode ser desenvolvida a partir de três motivações, que são a recreação, lazer e aprendizado, indo muito além da apreciação estética da paisagem, possibilitando que o visitante não apenas visite, mas que também conheça sobre a história geoevolutiva e histórico-cultural da feição geomorfológica. O geoturismo deve ser desenvolvido com base nos princípios da sustentabilidade e interpretação ambiental, que torna a linguagem geocientífica acessível ao público leigo, perfazendo desta forma, uma ponte entre a forma visitada e os visitantes (Moreira, 2012).

Compreendendo uma diversidade de formas de relevo que são atrativas para o desenvolvimento do geoturismo, o carste tradicional, associado às rochas carbonáticas como o calcário, presente em toda a extensão e limites do Parna Furna Feia, envolvem processos dinâmicos de dissolução e sedimentação do carbonato de cálcio, no caso do Parque, bem como processos físicos atuantes que proporcionam o aparecimento de feições em micro, meso ou macroescala em superfície e subsuperfície, que podem deter relevância em relação ao aspeto científico/educativo, cênico, ecológico, cultural e geoturístico (Lobo et al., 2007).

Dessa forma, tem-se o património geomorfológico cárstico, que pode compreender as formas do relevo cárstico que se destacam, sendo estes os Geomorfossítios cársticos, que englobam uma diversidade de feições na paisagem com potencial científico, educativo, ecológico, cênico e outros, importantes a serem resguardados, inseridos em estratégias de geoconservação e de promoção do turismo sustentável.

Ao longo do tempo, as principais formas cársticas comumente utilizadas para atividades de visitação foram as cavernas. Por serem feições subterrâneas que possuem características geológicas, morfológicas, climáticas e bióticas que se diferenciam do ambiente externo, 
tornaram-se atrativos para populações que buscam em espaços naturais o desenvolvimento de atividades que se diferem daquelas desenvolvidas no seu cotidiano, particularmente em espaços urbanos.

Quando há o interesse e a motivação de se conhecer e não apenas de visitar as formas significativas do relevo, o geoturismo se torna uma atividade imprescindível a ser desenvolvida, principalmente em unidades de conservação, já que estas são o alvo da procura de ambientes que possam oferecer o contato com a natureza mediante a interpretação ambiental (Lobo, Perinotto \& Boggiani, 2008).

\section{Materiais e Métodos}

A metodologia do presente trabalho se embasa em pesquisa qualitativa, por meio do uso de pesquisas bibliográficas. Foram também realizadas pesquisas de campo, que tiveram como intuito o conhecimento, identificação e caracterização do património geomorfológico cárstico do Parque Nacional da Furna Feia, o que deu origem a uma inventariação.

A inventariação foi desenvolvida em três etapas, sendo estas: Seleção prévia dos Geomorfossítios cársticos do Parna Furna Feia, a partir da junção dos métodos $\mathrm{Ad}-\mathrm{Hoc}$ e Seleção por Características Superlativas; Desenvolvimento de pesquisas de campo para a avaliação dos Geomorfossítios com base nos Valores Científico, Turístico, Ecológico e Cultural, avaliados em Baixo, Médio e Alto; e Caracterização dos Geomorfossítios selecionados. No desenvolvimento dos campos, foram realizadas descrições e anotações, além de registro fotográfico. A metodologia de inventariação foi adaptada das metodologias de Brilha (2015) e Pereira (2006). As etapas são detalhadas no quadro 1.

Os Geomorfossítios inventariados foram também avaliados quanto à escala em que se apresentam. Para isto, utilizou-se de uma adaptação da proposição de compartimentação de escalas realizado por Vieira (2014). Diante disso, os Geomorfossítios cársticos foram classificados como de Escala Local, para os Geomorfossítios de pequenas dimensões até uma dezena de metros, que apresentam pouco volume, extensão e desenvolvimento (Ex.: afloramento e caverna de pequenas dimensões); Escala de Área, para os Geomorfossítios que apresentam grandes dimensões na ordem de dezenas e até centenas de metros, 
proporcionando a movimentação para a observação dos elementos que apresentam (Ex.: cavernas de dimensões métricas até um quilômetro); bem como a Escala de Paisagem, que se caracteriza por ser um ponto de observação, havendo a possibilidade de se observar outros Geomorfossítios, proporcionando a visualização ampla no que tange aos elementos bióticos e culturais e suas relações na ordem de vários quilômetros (Ex.: mirantes).

Quadro 1 - Procedimentos metodológicos para a inventariação do Património Geomorfológico do Parna Furna Feia.

Primeira Etapa: Seleção prévia dos geomorfossítios cársticos da área do Parna Furna Feia

Aspetos considerados para a seleção prévia

Pesquisas em materiais bibliográficos para a seleção aleatória com base em características superlativas (Método Ad Hoc e Seleção por Características Superlativas), no qual levou em consideração, em caráter principal, os Geomorfossítios que são mais amplamente conhecidos na área e também que possuem características que os tornam atrativos para o desenvolvimento do geoturismo.

\section{Segunda Etapa: Pesquisas de campo para avaliação dos valores}

Valor Científico

Relacionado a importância do geomorfossítio como elemento que deve ser conservado para a investigação científica. Além disso, avalia-se a existência de trabalhos científicos (artigos, monografias, dissertações, teses, dentre outros) que discutam o geomorfossítio avaliado e sua potencialidade para ser utilizado como recurso didático através da facilidade em demonstrar processos geológicos e geomorfológicos.

\section{Valor Turístico}

Relacionado ao potencial estético do geomorfossítio, acesso fácil e boas condições de observação. É avaliada também, a dimensão do geomorfossítio e sua interação com outros elementos como flora, fauna e recursos hídricos, bem como com os elementos culturais.

\section{Valor Ecológico}

Relacionado à associação entre os elementos da flora e fauna com os elementos geológicos/geomorfológicos no geomorfossítio e que podem ser facilmente observados. Além desta associação, avalia-se a capacidade dos elementos geomorfológicos suportarem habitats característicos.

\section{Valor Cultural}

Relacionado à associação do geomorfossítio com elementos e atividades humanas do lugar em que está situado, tanto relacionado ao contexto do geomorfossítio enquanto suporte para atividades humanas, como também às modificações advindas de atividades humanas conferidas ao geomorfossítio, como por exemplo toponímias, registros arqueológicos e realização de eventos culturais.

Terceira Etapa: Caracterização dos Geomorfossítios selecionados (aspetos - Ficha A)

Caracterização adaptada de Brilha (2015)

- Proteção Legal

- Propriedade;

- Acessibilidade;

- Fragilidade e Vulnerabilidade;

- Descrição geológica e geomorfológica;

- Processos e formas da geodiversidade que possuem potencial para uso educativo e turístico;

- Limitações em relação ao uso do geomorfossítio para a atividade turística;

- Condições de Segurança (condições atuais para estudantes e turistas);

- Condições de observação;

- Registro fotográfico.

Fonte: Adaptado de Brilha (2015) e Pereira (2006) 
Diante disso, o inventário proposto é enquadrado como de reconhecimento, uma vez que foi realizado como uma primeira etapa de uma estratégia que pode fortalecer a geoconservação que é imposta na área, mediante a proposta de uso através do geoturismo (Pereira, 2010). Os Geomorfossítios foram inventariados por meio da aplicação de uma ficha de inventariação em campo (Ficha A) (Quadro 2).

Quadro 2 - Ficha de inventariação dos Geomorfossítios cársticos do Parna Furna Feia.

\begin{tabular}{|c|c|}
\hline Autor(a): & Data:________ \\
\hline \multicolumn{2}{|l|}{ GEOMORFOSSÍTIOS CÁRSTICOS } \\
\hline \multicolumn{2}{|l|}{$\begin{array}{l}\text { Nome: } \\
\text { Coordenadas Geográficas: Lat. }\end{array}$} \\
\hline \multicolumn{2}{|l|}{ Escala do Geomorfossítio } \\
\hline Local ( ) & Paisagem ( ) \\
\hline \multicolumn{2}{|c|}{ AVALIAÇÃO - Valores } \\
\hline \multicolumn{2}{|c|}{ 1. Valor Científio } \\
\hline Baixo ( ) & Médio ( ) \\
\hline \multicolumn{2}{|c|}{ 2. Valor Turístico } \\
\hline Baixo ( ) & Médio ( ) \\
\hline \multicolumn{2}{|c|}{ 3. Valor Ecológico } \\
\hline Baixo ( ) & Médio ( ) \\
\hline \multicolumn{2}{|c|}{ 4. Valor Cultural } \\
\hline Baixo ( ) & Médio ( ) \\
\hline \multicolumn{2}{|c|}{ CARACTERIZAÇÃO } \\
\hline \multicolumn{2}{|l|}{ 1. Proteção Legal } \\
\hline \multicolumn{2}{|l|}{ 2. Propriedade } \\
\hline \multicolumn{2}{|l|}{ 3. Acessibilidade } \\
\hline \multicolumn{2}{|l|}{ 4. Fragilidade e Vulnerabilidade } \\
\hline \multicolumn{2}{|l|}{ 5. Descrição Geológica e Geomorfológica } \\
\hline \multicolumn{2}{|c|}{ 6. Processos e formas da geodiversidade que possuem potencial para uso educativo e turístico } \\
\hline \multicolumn{2}{|c|}{ 7. Limitações em relação ao uso do geomorfossítio para a atividade geoturística } \\
\hline \multicolumn{2}{|c|}{ 8. Condições de Segurança } \\
\hline \multicolumn{2}{|l|}{ 9. Condições de Observação } \\
\hline 10. Registro fotográfico & \\
\hline
\end{tabular}

Fonte: Adaptado de Brilha (2015) e Pereira (2006).

Para a elaboração de mapas, fez-se o uso do software de geoprocessamento QGis(C na versão 2.14.8, com a utilização das bases de dados do Instituto Chico Mendes de Conservação da Biodiversidade (ICMBIO, 2012), Centro Nacional de Pesquisa e Conservação de Cavernas (CECAV, 2018), Departamento Nacional de Infraestrutura de Transportes (DNIT, 2015), Instituto Nacional do Semiárido (INSA), Ministério de Meio Ambiente (MMA), Serviço Geológico do Brasil (CPRM, 2006), Instituto Brasileiro de Geografia e Estatística (IBGE) e Instituto Nacional de Pesquisas Espaciais (INPE, 2015). Além disso, foram utilizados dados coletados em campo por meio da utilização de equipamento GPS (Sistema de Posicionamento Global). 


\subsection{Localização e breve caracterização geológica e geomorfológica da área de estudo}

Situado na Mesorregião Oeste do estado do Rio Grande do Norte (RN) e na Microrregião de Mossoró, entre os municípios de Mossoró e Baraúna (Figura 1), o Parque Nacional da Furna Feia possui uma área de 8.494 hectares na área oficial e 25.322 hectares na sua Zona de Amortecimento (ZA). O parque é uma Unidade de Conservação (UC) federal da categoria de proteção integral, criada no ano de 2012, e onde se permite apenas o uso indireto dos recursos naturais, como o desenvolvimento do turismo pautado nos princípios da sustentabilidade e desenvolvimento de pesquisas científicas. Caracteriza-se por ser o primeiro parque nacional do Estado do RN. O principal acesso até ao Parque pode ser feito através da RN-015, rodovia estadual que liga os municípios de Mossoró e Baraúna, com posterior entrada na estrada que dá acesso à Comunidade de Juremal.

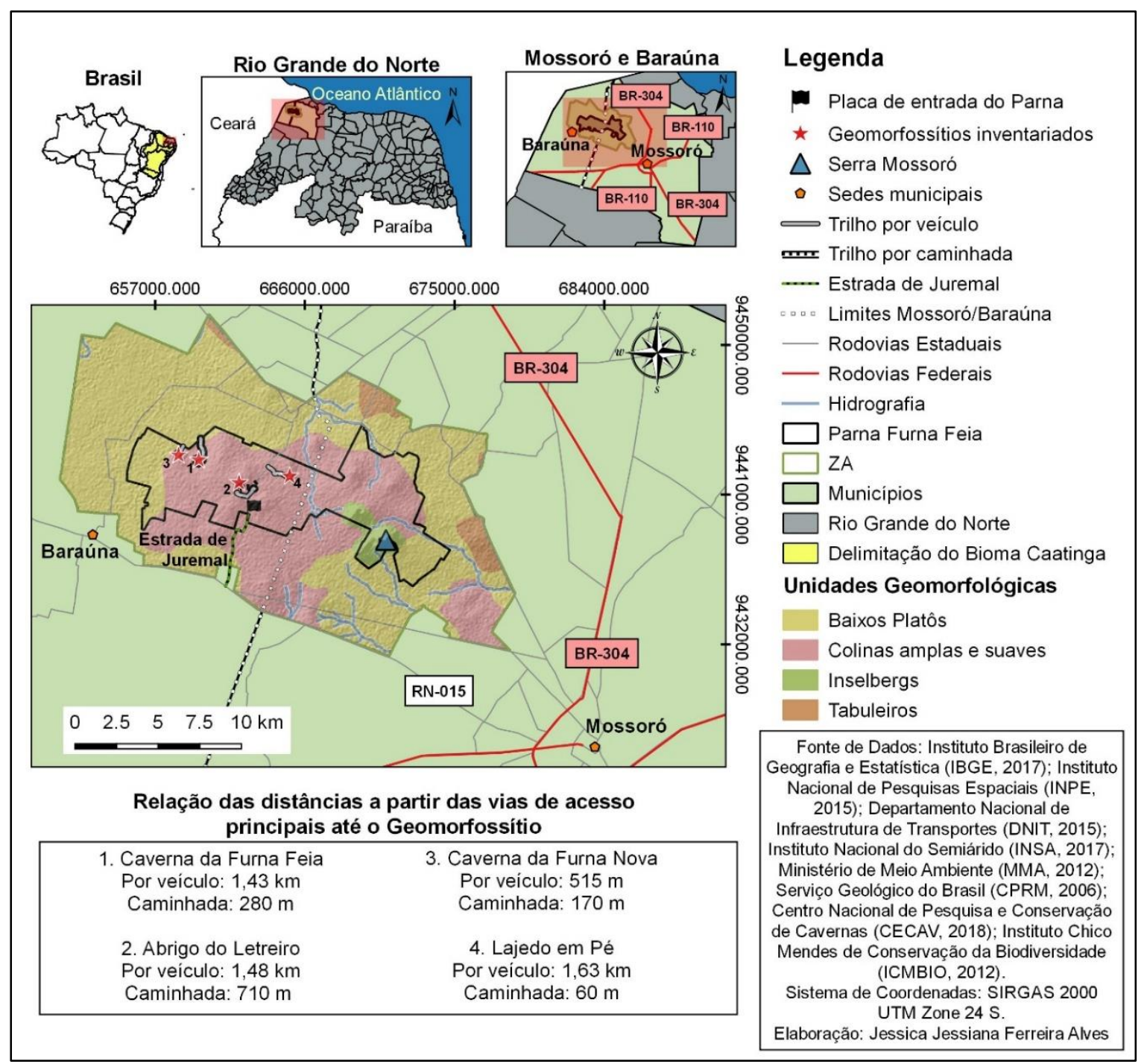

Fig. 1 - Mapa de localização do Parque Nacional Furna Feia.

Fonte: Elaboração própria 
No que concerne aos aspetos geológicos da área de estudo, o parque se situa na porção oeste da Bacia Potiguar. A evolução tectônica da Bacia está relacionada aos esforços extensionais que ocorreram durante o Cretácico Inferior (Neocomiano), que a partir do rifteamento, ocasionou a separação das placas sul-americana e africana e, consequentemente, o nascimento do Oceano Atlântico (Angelim, 2007).

$\mathrm{Na}$ área do parque predomina a Formação Jandaíra, uma das formações que compõem o Grupo Apodi da Bacia Potiguar. Esta Formação é datada do Cretácico (Turoniano a Eocampaniano) e compreende uma extensa porção de rochas carbonáticas aflorantes. Juntamente com os arenitos da Formação Açu (Grupo Apodi), o limite do pacote que corresponde às rochas carbonáticas da Formação Jandaíra, representa o limite de transgressão marinha máxima do Cretácico Superior na Bacia (Pessoa Neto et al., 2007).

Já no que concerne aos aspetos geomorfológicos, a área de estudo está situada, em quase sua totalidade, na Chapada do Apodi. Esta chapada é composta pelos afloramentos da plataforma carbonática da Formação Jandaíra, onde se destaca a ocorrência de um relevo cuestiforme, a qual se expressa na paisagem pelo Planalto em forma de Chapada do Apodi (Diniz et al., 2017). Com base no mapeamento de geodiversidade (vide figura 1), grande parte da área do Parna Furna Feia encontra-se inserida no Domínio dos Baixos Platôs da Bacia Potiguar, além do predomínio de formas tabulares pertencentes a Chapada do Apodi. Em menores porções da área ocorre o Domínio de Colinas amplas e suaves, como também inselbergs e outros relevos residuais, no qual se inclui a única formação geomorfológica positiva, a Serra Mossoró.

A área do Parna Furna Feia é resultante de um soerguimento tectônico da Plataforma de embasamento Aracati nas rochas calcárias pertencentes à Formação Jandaíra. Este soerguimento se manifesta com significativa evidência na região onde se localizam os municípios de Mossoró e Baraúna, notável pela Serra Mossoró, com sua maior porção localizada na ZA do Parna. Este soerguimento, juntamente com os processos de drenagem superficial e subterrânea, proporcionou a origem de diversas feições, como afloramentos, popularmente conhecidos como lajedos, e também cavernas, havendo um total de 250 , no conjunto da área oficial do Parna e da sua ZA. Deste conjunto, destaca-se um significativo património geomorfológico cárstico, que será discutido a seguir. 


\section{Resultados e Discussão}

O património geomorfológico cárstico inventariado no Parna Furna Feia é constituído por quatro Geomorfossítios, sendo três cavernas e um lajedo de grande relevância, tanto na perspetiva geológica/geomorfológica, quanto na perspetiva histórico-cultural, cênica e paisagística, o que justifica o grande potencial para o desenvolvimento do geoturismo na área e região. Estes Geomorfossítios são: Caverna da Furna Feia, Abrigo do Letreiro, Caverna da Furna Nova e Lajedo em Pé.

\section{- Caverna da Furna Feia}

O geomorfossítio cárstico Caverna da Furna Feia está situado na porção leste do Parna Furna Feia, no município de Baraúna. Possui coordenadas geográficas UTM longitude 659618.33 E; latitude - $9443083.15 \mathrm{~N}$ e o acesso até ao geomorfossítio é considerado muito fácil, sendo feito a partir da estrada que dá acesso a Comunidade de Juremal. O trajeto a pé até ao geomorfossítio é feito através de caminhada sobre o Lajedo da Furna Feia onde, logo abaixo deste, encontra-se a caverna. Este afloramento possui relevante beleza cênica e grande extensão, além de potencial científico e ecológico, pela presença de campo de lapiás, marmitas e dolinas de dissolução, além de uma diversidade de espécies da flora e da fauna do Bioma Caatinga, como macambiras (Bromelia laciniosa) e mocós (Kerodon rupestres), um tipo de roedor.

A caverna da Furna Feia possui diversos atributos que apresentam grande relevância e apelo para o desenvolvimento do geoturismo, pela presença de alto valor científico, ecológico, cultural e turístico. É a maior e mais conhecida caverna do Parna, sendo responsável por dar nome à UC. Caracteriza-se por ser um geomorfossítio de escala área, que apresenta aspetos de relevância em volume e extensão, em âmbito local e estadual, com $750 \mathrm{~m}$ de desenvolvimento linear, sendo este um dos atributos de relevância máxima da caverna de acordo com o ICMBIO e Centro Nacional de Pesquisa e Conservação de Cavernas (CECAV). A caverna apresenta três níveis conhecidos, sendo o primeiro e o segundo acessíveis, no qual 
é permitida a visitação, enquanto o terceiro se encontra inacessível e activo, não recebendo visitação.

A caverna apresenta alto valor científico devido à presença de diversas formas esculpidas nas rochas calcárias. Isto ocorre devido aos processos de dissolução e sedimentação atuantes no ambiente cavernícola, ao longo de milhares de anos, nos primeiro e segundo níveis. Estes processos, apesar de serem pouco intensos na atualidade, demonstram forte atividade em épocas pretéritas, o que, ao longo de milhares de anos, resultou no desenvolvimento da caverna, que possui um desnível total de 30 m (ICMBIO; CECAV, 2011), apresentando dimensões notáveis (Figura 2-A e 2-B).

O valor científico corrobora com a presença de outro atributo de relevância máxima da caverna. Este atributo se deve à presença de espeleotemas únicos, encontrados somente nesta caverna. Os espeleotemas podem ser observados em praticamente todo o desenvolvimento, sendo possível a fácil observação nos dois níveis acessíveis e com alto valor interpretativo.

Alguns destes espeleotemas são: grandes e abundantes escorrimentos calcíticos (Figura 2C), sendo que a caverna apresenta os maiores do parque; colunas (Figura 2-D), formadas a partir da união de uma estalactite com uma estalagmite; travertinos (Figura 2-E), no qual a caverna apresenta os maiores travertinos do parque, que possuem porte métrico, detendo elevado apelo cênico. Além dos espeleotemas, há também a presença de uma geoforma que possui valoroso apelo cênico e valor científico. Esta é a "Pedra da cabeça do tubarão" (Figura 2-F), na qual a atuação de processos de dissolução e de fraturamentos sobre a rocha calcária, durante milhares de anos, resultou em uma formação que remete a uma cabeça de um tubarão, já permeada no imaginário popular.

Além de elevado valor científico, a caverna da Furna Feia também apresenta alto valor ecológico, que é justificado pela presença de uma grande diversidade de espécies, principalmente da fauna. Este alto valor ecológico também foi razão para a atribuição de relevância máxima ao geomorfossítio, que é o habitat de troglóbios raros (Bento et al., 2013). 


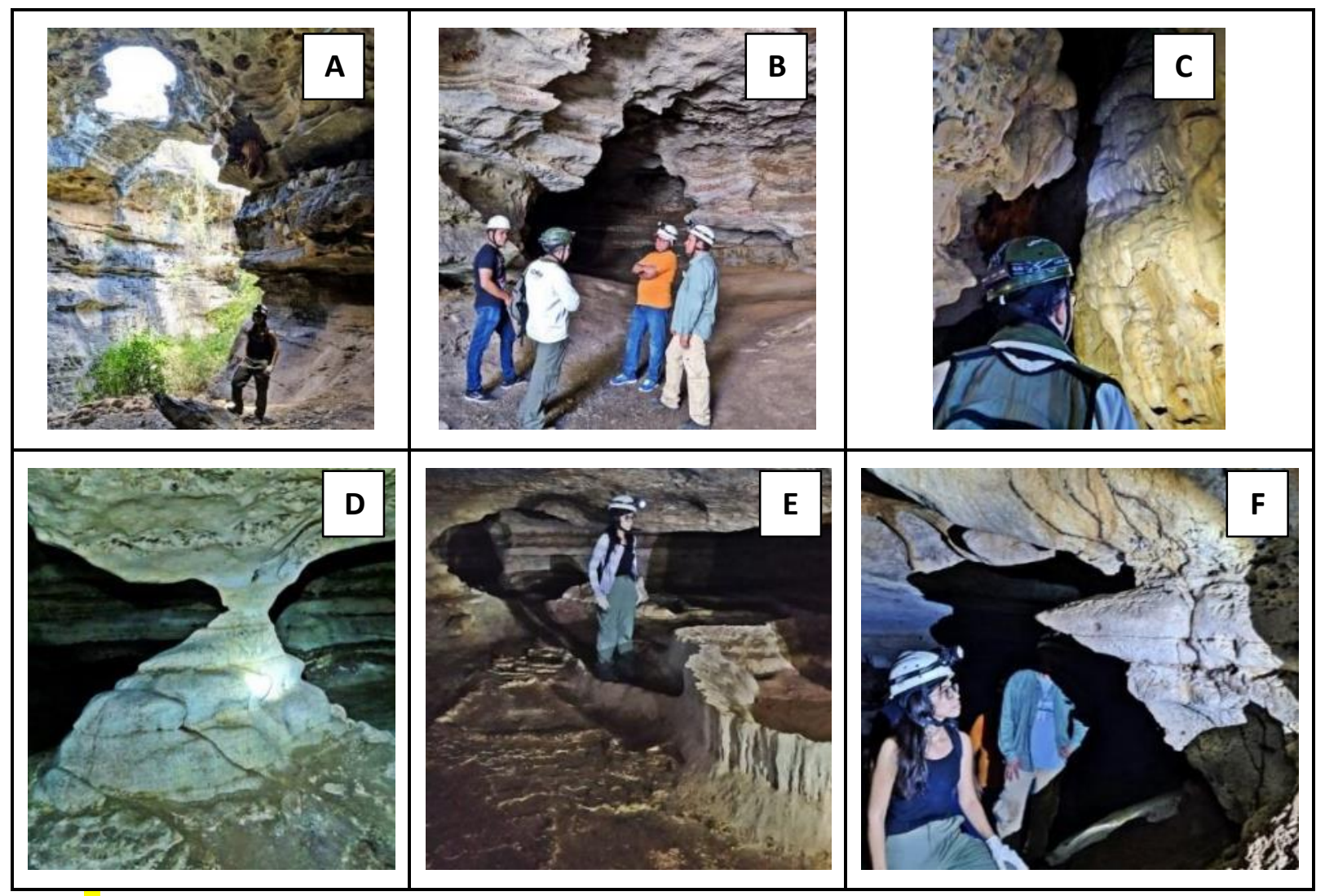

Fig. 2 - Entrada da caverna da Furna Feia (A e B), os maiores escorrimentos calcíticos do parque (C), colunas (D), os maiores travertinos do parque (E); e a forma "Pedra da cabeça do tubarão" (F).

Fonte: Elaboração própria, recolhidas em 2019.

De acordo com o ICMBio e CECAV (2011), há duas grandes colônias de morcegos insetívoros e hematófagos que habitam o segundo nível da caverna. O local de habitat destes animais é marcado por vestígios de sua ocupação no tecto e chão da caverna, pela existência de manchas e guano, respectivamente. Além de morcegos, há também a presença de animais como sapos e pererecas, bem como diversos tipos de aracnídeos, como os amblipígios.

O alto valor científico do geomorfossítio, juntamente com o alto valor ecológico, demonstram fortemente a interdependência existente entre os elementos da geodiversidade e biodiversidade. Não somente para espécies da flora e da fauna, o ambiente cavernícola também foi e é essencial para o ser humano. O geomorfossítio caverna da Furna Feia possui também um elevado valor cultural, por ser considerado pelas populações mais antigas que residem no entorno, o símbolo de sua região. Há relatos de que esta caverna foi descoberta por estas populações ainda na primeira metade do século $\mathrm{XX}$, sendo as primeiras a saber de sua existência. Desde então, a área do atual Parna Furna Feia, bem como a caverna da Furna Feia, representam o palco para o conto de muitas 
histórias da região. Muitas já estão permeadas no imaginário popular, como, por exemplo, os relatos de que a caverna seria o abrigo de almas e fantasmas de antigos moradores do entorno. Além disso, o Parna Furna Feia possui relevância para as comunidades locais, seja por abrigar as belezas de sua região, através da existência das cavernas e da paisagem que integra geo e biodiversidade, seja pela existência de plantas medicinais que se encontram no seu entorno, como também no entorno de outras cavernas que integram o Parque. A existência destas plantas e sua utilização local permitem a reprodução cultural destas populações tradicionais.

Os valores científico, ecológico e cultural sintetizam um elevado potencial da caverna para o uso geoturístico. Algumas limitações se impõem a este potencial, como, por exemplo, a presença de lances verticais bem como algumas deteriorações antrópicas, uma vez que, sendo a caverna mais conhecida da área do Parna, sofreu visitação desordenada no período anterior à criação da UC, o que resultou em pichações e em outras deteriorações, porém, apesar disso, a caverna se encontra predominantemente conservada. Outra limitação se constitui pela presença de colônias de morcegos na caverna, devendo a prática geoturística ser planeada, com imposição de restrições em determinados momentos e visando à minimização de impactes na dinâmica natural das diversas espécies de morcego que habitam a caverna. Soma-se ao potencial geoturístico, a proximidade do geomorfossítio da via principal de acesso, sendo o trajeto considerado fácil, com excelentes condições de observação, tanto no trilho, como no interior da caverna.

\section{- Abrigo do Letreiro}

O geomorfossítio cárstico Abrigo do Letreiro está localizado na porção central do Parna Furna Feia, no município de Baraúna, com coordenadas geográficas UTM longitude 662038.30 E; latitude - 9441716.26 N. Há uma lagoa intermitente nas proximidades do geomorfossítio, que seca em período de estiagem, conhecida como Lagoa do Pinga, uma provável dolina de dissolução que possui em torno de 1,5 hectares de diâmetro, o que aumenta o potencial interpretativo do trilho e do geomorfossítio Abrigo do Letreiro.

Ao longo do trilho, é possível observar diversas espécies nativas do Bioma Caatinga, como a macambira (Bromelia laciniosa) e o facheiro (Pilosocereus pachycladus), sendo que há 
espécies antigas de facheiros que são bioindicadores da boa qualidade ambiental do local. Essa característica demonstra a relevância da paisagem cárstica do Parna em termos de valor ecológico (Pereira, 2006).

Mesmo tendo sido denominado de abrigo, tecnicamente, a formação é uma caverna, por apresentar desenvolvimento maior que a altura da entrada. Entretanto, devido a algumas características, onde a largura é mais notável do que a profundidade, além da ausência de áreas afóticas, estes são fatores importantes que podem caracterizar a formação como um abrigo, ainda reforçados por vestígios de ocupação humana pretérita.

O Abrigo do Letreiro é um geomorfossítio de escala área, por permitir maiores deslocamentos para a observação de seus atrativos, possuindo $50 \mathrm{~m}$ de desenvolvimento horizontal e com excelentes condições de observação (Figura 3-A). O geomorfossítio se destaca na paisagem cárstica da área, uma vez que os processos de soerguimento da plataforma carbonática Jandaíra, com o posterior processo de dissolução de carbonatos mais suscetíveis em seu interior, deram origem ao Abrigo do Letreiro, que se apresenta em um nível mais elevado em relação à topografia predominante.

O geomorfossítio apresenta um único nível e duas entradas principais que atravessam toda a caverna. Apesar de pouco desenvolvimento, apresenta um largo salão no qual há a passagem de correntes de ar, tornando o ambiente agradavelmente fresco. Ao lado da entrada, o geomorfossítio apresenta um outro salão, que possui pequenas dimensões se comparado ao salão principal, mas que apresenta relevância em termos de valor ecológico, uma vez que é o habitat de uma colônia de morcegos.

Este valor também é ressaltado pela presença e interação de espécies da flora na caverna, como por exemplo o Mulungu (Erythrina velutina Willd.), que se desenvolveu na porção do abrigo onde há uma maior incidência direta da luz solar que atravessa e ilumina quase todo o desenvolvimento da caverna, em razão da presença de uma claraboia. Esta se encontra na porção central do tecto (Figura 3-B), e é conhecida como a claraboia do Mulungu, que expressa elevado valor cênico. No mesmo local, observa-se, também, a presença de uma jurema-preta (Mimosa tenuiflora), umas das espécies pioneiras da caatinga. 


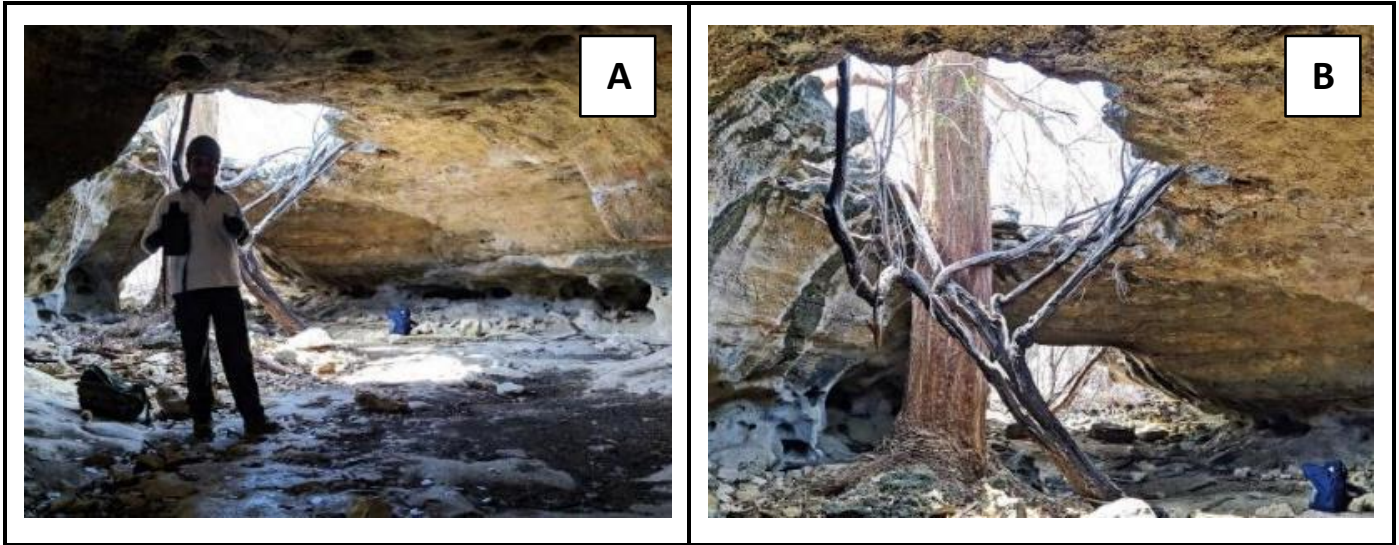

Fig. 3 - Salão principal do Abrigo do Letreiro (A) e claraboia do Mulungu (B).

Fonte:Elaboração própria, recolhidas em 2019.

Outro aspeto que atribui à caverna uma elevada relevância, somado aos já apresentados aqui, é o aspeto arqueológico. Há no geomorfossítio uma quantidade significativa de registros rupestres que se encontram no tecto e nas paredes, o que justifica o nome da caverna e configura um alto valor cultural da mesma. Povos antigos em busca de abrigo encontraram, nesta formação, algumas condições essenciais para a sua sobrevivência.

Apesar de ainda não haver estudos aprofundados sobre os registros rupestres, acredita-se que estes estão associados à Tradição Agreste, com uma possível variedade, tipo ou tendência geométrica, já que grande parte dos símbolos possuem características abstratas e geométricas. Segundo Martin (2005), a Tradição Agreste está fortemente presente na região Nordeste, principalmente em Pernambuco e na Paraíba, onde apresenta os mesmos horizontes culturais no estado do RN, mediante a descoberta dos registros rupestres em outro sítio arqueológico, que é o Lajedo de Soledade, localizado no município de Apodi. Os grupos humanos desta tradição estão associados a caçadores-coletores que partilhavam de um clima semelhante ao atual, há aproximadamente 5.000 anos (Martin, 2005).

São percetíveis símbolos circulares que podem indicar a representação de astros. Há também setas (Figura 4-A) e representações que demonstram a contagem no tempo, pela presença de linhas paralelas (Figura 4-B). Há, ainda, símbolos relacionados com triângulos preenchidos (Figura 4-C) e outros que lembram zoomorfos, apesar de não haver estudos que possam confirmar estas proposições. A figura 4-D apresenta um símbolo que faz lembrar um tatu, mamífero da ordem Cingulata, bastante comum na área do Parna. 


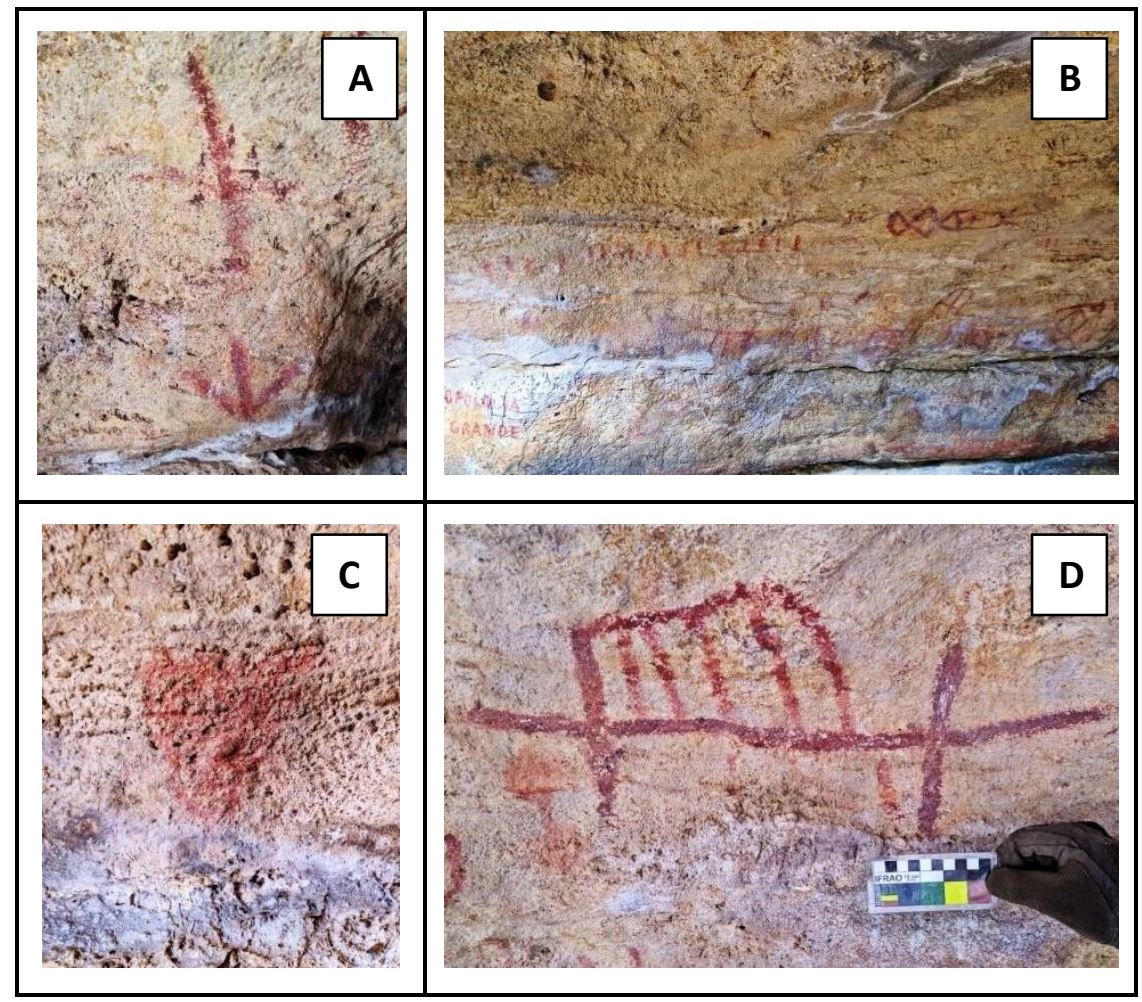

Fig. 4 - Registros rupestres no Abrigo do Letreiro.

Fonte: Elaboração própria, recolhidas em 2019

Todos os símbolos estão representados na cor vermelha, possuindo tamanhos variados e, pela espessura dos traços, demonstram que foram pintados com as pontas dos dedos. A Tradição Agreste, ainda segundo Martin (2005), demonstra indícios de ocupação humana, diferentemente da Tradição Nordeste, em que os locais constatados remetem a sítios de cerimônia. Justificativas relevantes a este processo de ocupação no geomorfossítio podem ser explicadas mediante a presença e proximidade da Lagoa do Pinga, que em tempos passados poderia se encontrar alagada por períodos mais longos. Outra possível justificativa é a proximidade do Abrigo do Letreiro com a Gruta do Pinga, um sumidouro em que ocorre gotejamento perene, o que pode ter constituído uma fonte para a sobrevivência de grupos humanos no passado.

Vale ressaltar que apenas com estudos mais aprofundados poderá ser comprovado, de facto, a que tradição os grafismos do geomorfossítio pertencem. Diante disso, o geomorfossítio possui um elevado potencial interpretativo que pode ser inserido em estratégias que visem ao desenvolvimento da atividade geoturística, pois apresenta um alto valor turístico, ecológico e, principalmente, cultural. Apresenta, também, alto valor científico, por demonstrar processos da evolução cárstica de superfície em excelentes 
condições de observação bem como pela presença de espeleotemas, porém de porte centimétrico e de difícil observação.

O valor turístico é ressaltado como alto, em razão da proximidade do geomorfossítio com a via principal de acesso, além da presença de apelo cênico e de aspetos já tratados. Entretanto, vale destacar que, segundo informações de gestores do Parna, estão previstas pequenas intervenções no que concerne à instalação de estruturas que visem a facilitar a visitação turística, além de estruturas de acessibilidade para que o geomorfossítio também possa receber visitantes com deficiência física, o que se constituirá como a primeira caverna com acessibilidade a pessoas com deficiência ou com limitações de mobilidade no Brasil. Porém, vale salientar que o uso geoturístico deste Geomorfossítio deve estar pautado em um planeamento adequado, levando-se em conta a capacidade de carga do ambiente, de modo a minimizar os impactes ambientais desta atividade.

\section{- Caverna da Furna Nova}

O geomorfossítio cárstico Caverna da Furna Nova está localizado na porção leste do Parna Furna Feia, nas proximidades da caverna da Furna Feia. O geomorfossítio possui coordenadas geográficas UTM longitude - 658398.72 E e latitude - $9443381.84 \mathrm{~N}$ e o acesso é muito fácil por estradas vicinais em boas condições de tráfego e, posteriormente, por trilho.

A caverna é um geomorfossítio de escala área, sendo representativo em relação ao desenvolvimento horizontal com $250 \mathrm{~m}$, consituindo-se como a segunda maior caverna da área do Parna. Apresenta excelentes condições de observação de seus atrativos, que estão presentes tanto no entorno, quanto em seu interior. Diante disso, o potencial interpretativo é elevado, pois demonstra processos e formas cársticas que contam a história evolutiva da caverna e permitem interpretar a evolução regional. Este potencial se inicia a partir dos afloramentos calcários situados no entorno da caverna, os quais compõem o Lajedo da Furna Nova. Nestes afloramentos podem ser encontrados campos de lapiás que demonstram processos ativos de dissolução da rocha, tanto em superfície, quanto em subsuperfície (Travassos et al., 2015). 
A caverna apresenta dois níveis, sendo que só o primeiro será aberto para visitação pública, uma vez que nele se concentram grande parte dos atrativos que justificam o seu elevado valor turístico, científico e ecológico. O acesso ao interior da caverna é feito a partir de uma fenda na rocha, aberta após um processo de abatimento de parte do tecto (Figura 5-A). Cicatrizes deste processo podem ser observadas nos blocos abatidos encontrados logo após passar pela entrada da caverna (Figura 5-B).

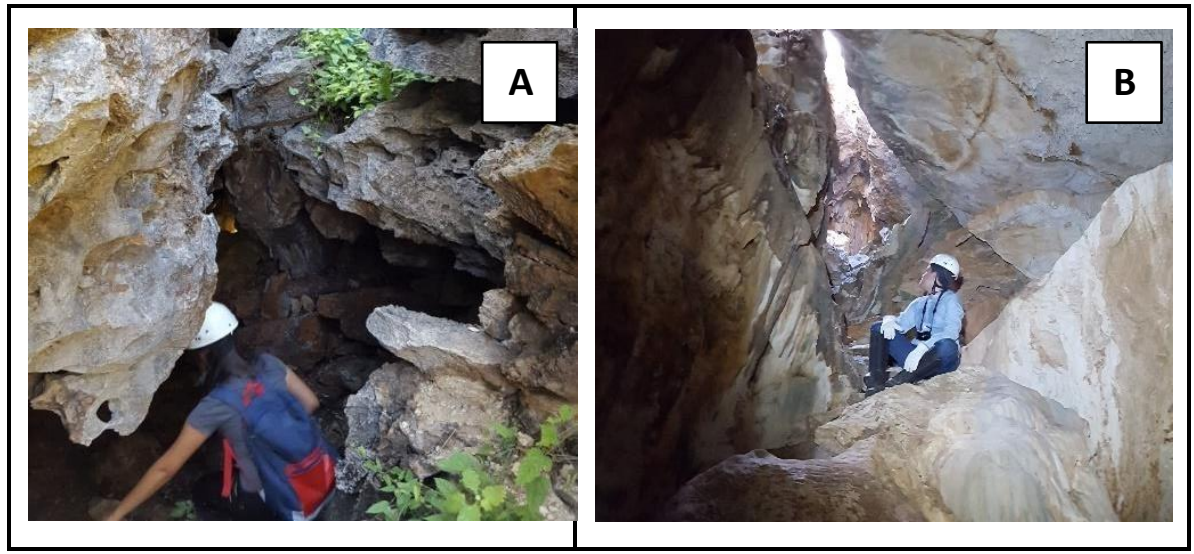

Fig. 5 - Entrada da Caverna da Furna Nova (A e B).

Fonte: Elaboração própria, recolhidas em 2019

O primeiro nível da caverna é representativo pela presença de diversos tipos de espeleotemas, atribuindo significativo valor científico/educativo e cênico ao geomorfossítio. Podem ser facilmente observados: estalactites (Figura 6-A); estalagmites em processo inicial de formação (Figura 6-B); escorrimentos calcíticos de variadas dimensões; microtravertinos, chão de estrelas pela cristalização da calcita, possuindo brilho vítreo ao incidir luz e detendo alto valor estético; ninho de pérolas (Figura 6-C); e cortinas, sendo que a Furna Nova detém a maior cortina do parque e do estado do Rio Grande do Norte, com mais de 6 metros de altura. Assim, compreende um alto potencial científico/educativo e valor estético, pela sua dimensão métrica (Figura 6-D) (Lobo et al., 2007; Travassos, 2015).

A presença desta cortina foi uma justificativa essencial para a atribuição da caverna como de relevância máxima pelo ICMBio e CECAV, no que concerne a presença de espeleotemas únicos, de acordo com a Instrução Normativa no 2, de 20 de agosto de 2009, do Ministério de Meio Ambiente. 


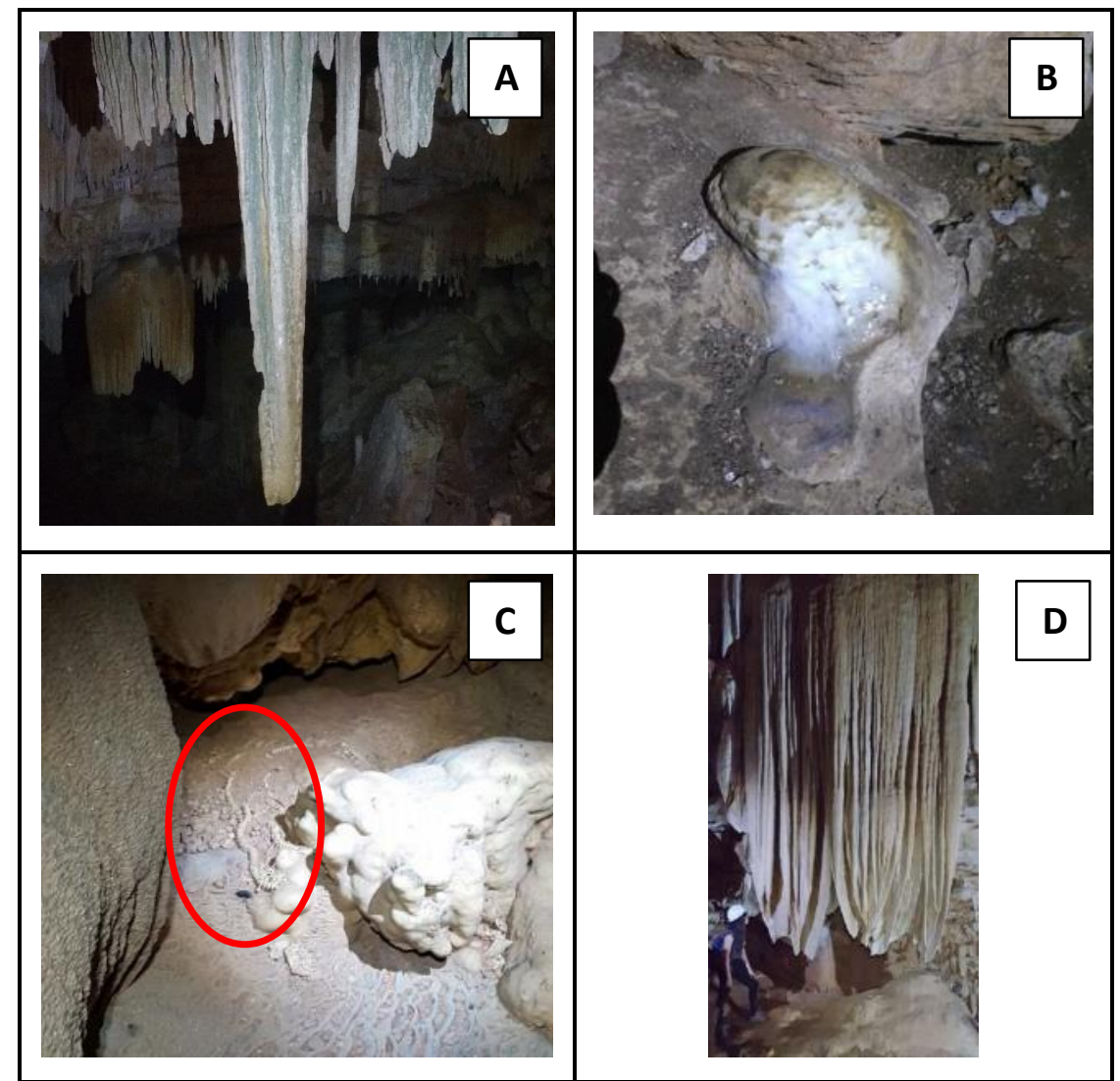

Fig. 6 - Espeleotemas da Caverna da Furna Nova. Destaque em contorno vermelho para ninho de pérolas ao lado de um esqueleto de serpente calcificado.

Fonte: Elaboração própria, recolhidas em 2019

Por possuir estas formações, o geomorfossítio apresenta condições de grande relevância para o desenvolvimento de atividades educativas e interpretativas, pesquisas científicas e, principalmente, para o desenvolvimento do geoturismo, uma vez que apresenta processos relevantes e atrativos para serem inseridos em estratégias de valorização e divulgação.

Soma-se ao alto potencial científico da caverna, o seu alto valor ecológico. Nos trabalhos de campo foram observados pequenos animais da fauna cavernícola, como aranhas, lagartos e morcegos, além de espécies típicas da vegetação de Caatinga, como a macambira (Bromelia laciniosa), observadas no entorno da caverna. Em seu interior, foram observados diferentes tipos de raízes e, também, um tronco calcificado. Em relação à fauna, além dos animais citados, a Furna Nova abriga animais em processo de fossilização que podem ser facilmente observados, com exemplo para o esqueleto calcificado de uma serpente (vide Figura 6-C).

Em relação ao valor cultural, não foram encontrados ou relacionados aspetos de grande relevância de interação entre o geomorfossítio em questão com elementos culturais 
pretéritos ou atuais, o que designou este valor como baixo. Entretanto, apesar de não haver registros arqueológicos identificados, a caverna pode ter-se constituído como abrigo em tempos pretéritos para populações humanas, já que há vestígios desta ocupação em outro geomorfossítio do parque, o Abrigo do Letreiro. Porém, no que concerne aos valores turístico, científico e ecológico, estes foram designados como altos, justificados pelos elementos e processos observados e descritos, o que atribui a caverna uma alta relevância para o desenvolvimento da atividade geoturística.

\section{- Lajedo em Pé}

O geomorfossítio cárstico Lajedo em Pé se localiza na porção central do Parna Furna Feia, município de Baraúna, e possui coordenadas geográficas UTM longitude - 665084.49 E; latitude - $9442107.32 \mathrm{~N}$. Possui acesso muito fácil por estradas vicinais/locais e posterior trilho, encontrando-se em boas condições de tráfego.

O local se caracteriza por ser um extenso afloramento calcário, considerado como um geomorfossítio de escala área, pois apresenta dezenas de metros de extensão, com características que permitem um maior deslocamento para a observação dos atrativos, possuindo excelentes condições em relação à observação. Os processos de soerguimento na área do Parna Furna Feia proporcionaram, neste local, a exposição das rochas carbonáticas que, com a atuação de processos de intemperismo químico (mediante a dissolução da rocha), apresentam-se, atualmente, intensamente carstificadas, com coloração cinza escura.

Este extenso afloramento, popularmente conhecido como lajedo, apresenta características curiosas e significativas do ponto de vista cultural. O alto valor cultural é logo identificado pela presença de uma grande quantidade de rochas que estão dispostas na posição vertical, encaixadas em vãos abertos no afloramento que se originaram por processos de intemperismo e de fraturamentos. É em razão desta característica marcante que foi designado o nome do afloramento de Lajedo em Pé (Figura 7-A).

Aparentemente, grupos humanos pretéritos, provavelmente os mesmos grupos humanos que deixaram vestígios de ocupação no geomorfossítio Abrigo do Letreiro, realizaram estas modificações na paisagem cárstica do local. É visível que as rochas foram manualmente deslocadas para se encaixarem nas aberturas do lajedo, que se dispõem em toda a sua 
extensão. A justificativa que torna possível esta afirmação é pelo motivo de que as rochas do local, quando movidas, possuem cor creme esbranquiçada na parte inferior (Figura 7-B), enquanto em seu exterior, apresenta coloração cinza escuro (Figura 7-C), em razão do intenso processo de intemperismo. Além disso, de acordo com autoridades do ICMBio, moradores mais antigos das comunidades do entorno relatam que o local foi encontrado no estado em que se encontra na paisagem atual. Caso seja confirmada a sua origem antrópica pretérita, tal facto poderá vir a efetivar esta área como o segundo sítio arqueológico do Parna Furna Feia.

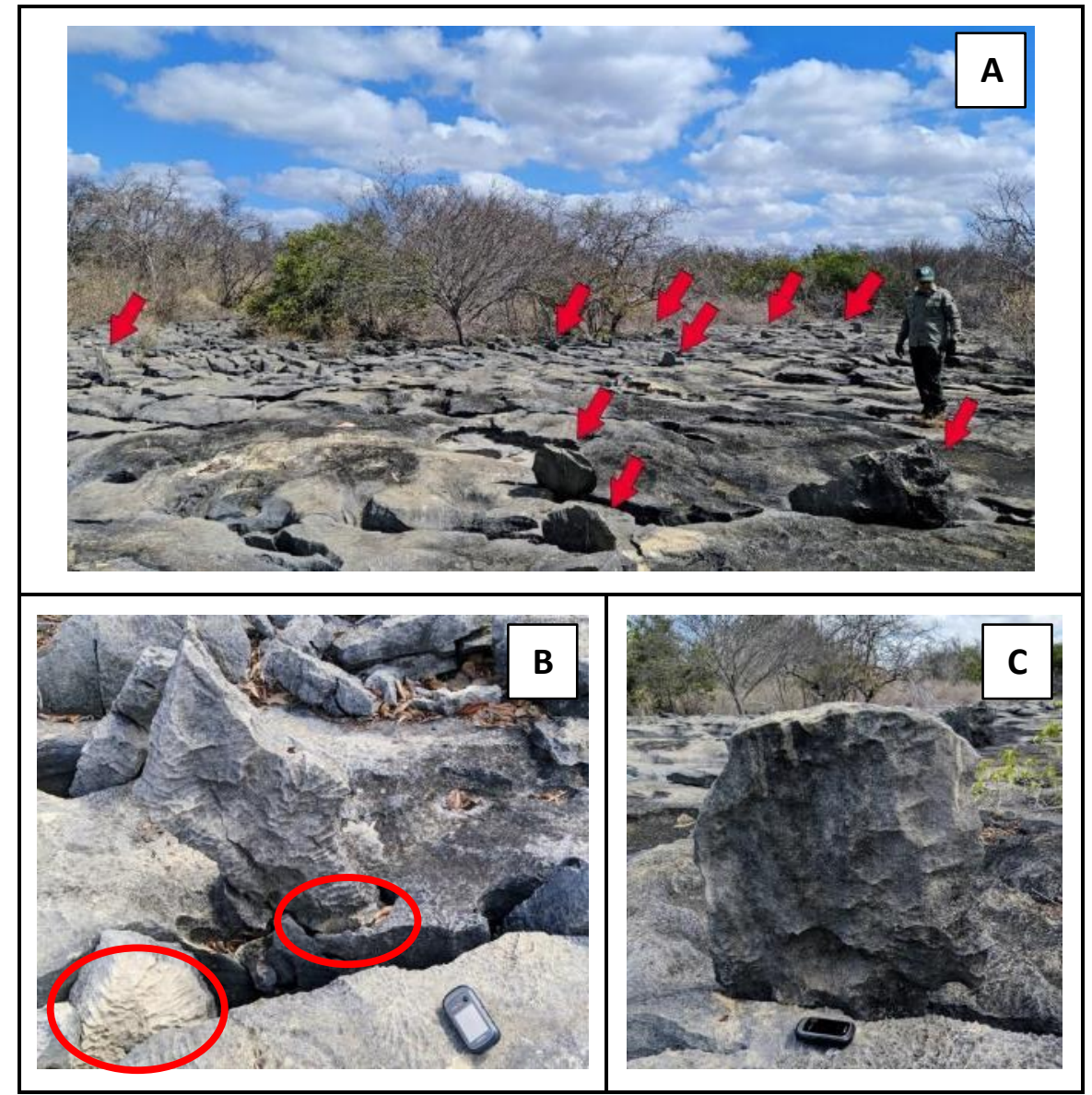

Fig. 7 - Geomorfossítio cárstico Lajedo em Pé. Afloramento com detalhe em setas vermelhas para rochas dispostas na posição vertical (A); Detalhe para rocha com parte inferior de coloração natural (B); Rocha na posição vertical (C).

Fonte: Elaboração própria, recolhidas em 2019.

Além do alto valor cultural, o geomorfossítio possui características significativas que justificam o seu valor científico, avaliado como alto, por apresentar formas e processos associados ao exocarste da área. São facilmente observáveis formações típicas, como 
campo de lapiás (Figura 8-A), que se apresentam em toda a extensão do afloramento, além de marmitas de dissolução (Figura 8-B).

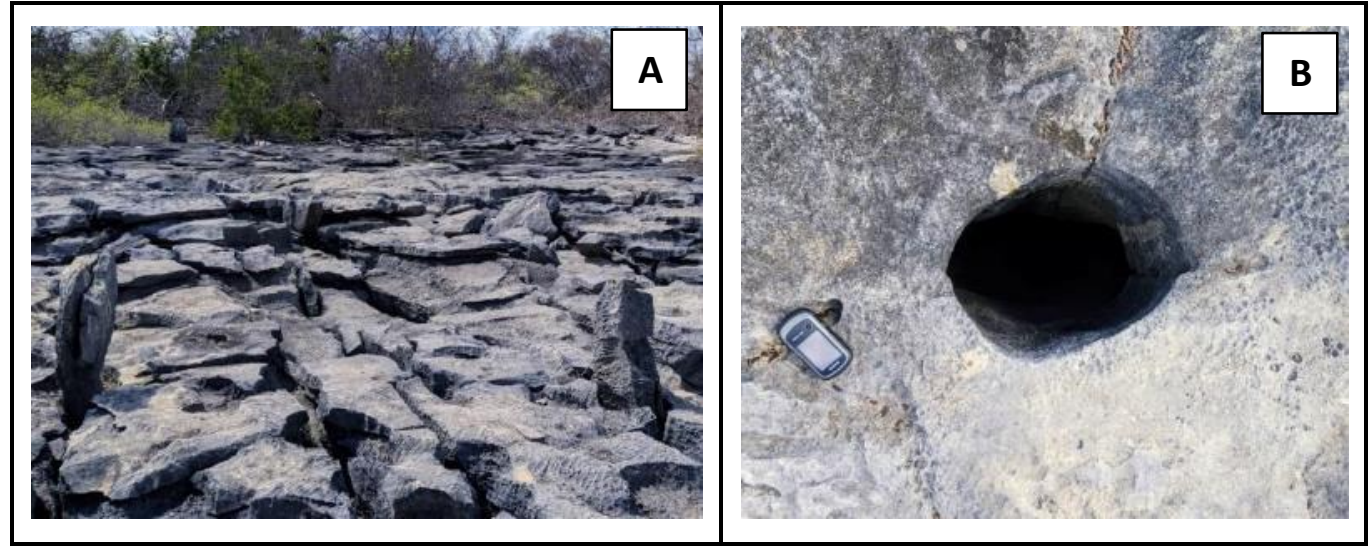

Fig. 8 - Feições exocársticas do Lajedo em Pé.

Fonte: Elaboração própria, recolhidas em 2019

A origem das marmitas pode ter ocorrido no tempo pretérito em que havia alagamentos intensos na área, bem como pela ação de águas meteóricas. As marmitas em rocha calcária estão associadas aos lapiás, pela dissolução superficial da rocha, o que aumenta o potencial interpretativo do geomorfossítio por demonstrar processos evolutivos exocársticos em excelentes condições de observação.

O alto valor ecológico também é bem evidenciado no geomorfossítio, uma vez que diversas espécies da flora podem ser observadas no local, como macambiras (Bromelia laciniosa) e facheiros (Pilosocereus pachycladus), além de espécies da fauna. Foi possível observar a presença de fezes de mocós (Kerodon rupestres), uma espécie de roedor da região, por toda a extensão do lajedo, que proporciona abrigo pare esta espécie de animal. Diante disso, este valor ecológico é, ainda, evidenciado pela presença de fatores que demonstram interdependência entre elementos da geodiversidade e biodiversidade (Pereira, 2006).

Dessa forma, o valor turístico do geomorfossítio é relevante, tendo sido avaliado como alto, pois possui atrativos que podem ser inseridos em estratégias de interpretação ambiental através do desenvolvimento da atividade geoturística. Com o desenvolvimento de estudos mais aprofundados sobre o aspeto histórico-cultural, mediante uma possível confirmação do geomorfossítio como o segundo sítio arqueológico da área, será enriquecido e fortalecido este potencial, pois se constituirá, provavelmente, como o primeiro sítio arqueológico do Brasil que apresenta estas características. 


\section{Síntese dos Resultados}

Uma vez avaliados e inventariados os principais Geomorfossítios do Parna Furna Feia, podese observar que quase todos os Geomorfossítios visitados in loco apresentam valores altos para todos os critérios considerados, sendo esses os Valores Científico, Turístico, Ecológico e Cultural, a partir da metodologia proposta para a realização deste estudo (Quadro 3).

Quadro 3 - Resultados simplificados da inventariação do Património Geomorfológico Cárstico do Parna Furna Feia.

\begin{tabular}{|c|c|c|c|c|}
\hline \multirow{2}{*}{ Geomorfossítios } & \multicolumn{4}{|c|}{ Valores } \\
\cline { 2 - 5 } & Valor Científico & Valor Turístico & Valor Ecológico & Valor Cultural \\
\hline Furna Feia & Alto & Alto & Alto & Alto \\
\hline Abrigo do Letreiro & Alto & Alto & Alto & Baixo \\
\hline Furna Nova & Alto & Alto & Alto & Alto \\
\hline Lajedo em Pé & Alto & Alto & Alto & \\
\hline
\end{tabular}

Fonte: Elaborado pelos autores.

A única exceção, diz respeito ao valor cultural observado na Furna Nova, ao qual se atribuiu valor baixo, tendo em vista que não foram encontrados ou relacionados aspectos de grande relevância em que haja interação entre o geomorfossítio em questão com elementos culturais pretéritos ou atuais. Apesar disso, salienta-se que a caverna pode ter-se constituído como abrigo em tempos pretéritos para populações humanas, já que há vestígios desta ocupação no Geomorfossítio Abrigo do Letreiro.

Desse modo, o Parque da Furna Feia possui alto potencial para o desenvolvimento da atividade geoturística, o que justifica a necessidade de geoconservação do seu património geomorfológico. Como forma de favorecer e fortalecer este desenvolvimento, faz-se mister a adoção de estratégias de valorização e divulgação desse património, possibilitando uma maior popularização do conhecimento geocientífico e de sua importância ambiental junto às populações locais e regionais, o que possibilita o fortalecimento da geoconservação dentro e para além dos limites do Parna.

\section{Considerações Finais}

A inventariação dos Geomorfossítios do Parna Furna Feia permitiu a identificação de um rico e relevante Património Geomorfológico, que apresenta quatro Geomorfossítios cársticos de alto potencial, sendo estes a caverna da Furna Feia, Abrigo do Letreiro, a caverna da Furna 
Nova e o Lajedo em Pé. Todos possuem relevância em razão de apresentam elevado valor científico, cultural, ecológico e turístico que, através de estratégias eficazes, poderão, futuramente ser aproveitados para o geoturismo.

Este património geomorfológico cárstico, envolve feições de grande expressividade que devem ser preservadas para que as presentes e futuras gerações possam se beneficiar de seus aspetos significativos, seja a partir de atividades de visitação para recreação, lazer e/ou aprendizado, com base nas concepções da sustentabilidade, seja para a investigação científica, o que promoverá um maior conhecimento de sua importância, tanto para a comunidade científica, quanto para a população em geral.

No que concerne à presença de conhecimento científico, mensurado a partir da existência de trabalhos científicos que façam menção aos Geomorfossítios, há ainda uma lacuna a ser preenchida. Apesar de haver trabalhos, como relatórios técnicos, artigos e monografias que discutem, principalmente, a Caverna da Furna Feia, Abrigo do Letreiro e Caverna da Furna Nova, estes Geomorfossítios são, ainda, pouco conhecidos e estudados, necessitando assim de estratégias que visem uma maior difusão da relevância deste património geomorfológico cárstico, que poderão proporcionar sua valorização e divulgação, tanto no meio científico, quanto para o público em geral.

Neste sentido, é válido destacar que se faz necessário o desenvolvimento de estratégias que promovam a conservação aliada ao uso sustentável deste património geomorfológico, mediante o desenvolvimento do geoturismo. Tais estratégias devem visar a geoeducação, bem como a interpretação ambiental, que por sua vez podem contribuir para a valorização e a divulgação deste geopatrimónio. O desenvolvimento do geoturismo poderá fortalecer o debate da geoconservação através da sensibilização de visitantes que, em integração com as comunidades, podem reforçar a integridade cultural e identidade local, além de proporcionar o desenvolvimento econômico local sustentável.

\section{Agradecimentos}

O presente trabalho foi realizado com o apoio da Coordenação de Aperfeiçoamento de Pessoal de Nível Superior - Brasil (CAPES) - Código de Financiamento 001. 
À equipe do Instituto Chico Mendes de Conservação da Biodiversidade e aos gestores e servidores do Parque Nacional da Furna Feia por todo o apoio logístico para a realização dos campos.

Ao Núcleo de Estudos Socioambientais e Territoriais (NESAT) da Universidade do Estado do Rio Grande do Norte (UERN), pelo espaço concedido para a realização de pesquisas e estudos.

\section{Referências Bibliográficas}

ANGELIM, Luiz Alberto de Aquino (2007). Geologia e recursos minerais do Estado do Rio Grande do Norte Escala 1:500.000. Recife: CPRM - Serviço Geológico do Brasil.

BENTO, D. M.; CRUZ, J. B.; DARCY, J. S.; FREITAS, J. I. M.; CAMPOS, U. P.; SOUZA, R. F. R. (2013). Parque Nacional da Furna Feia - o parque nacional com a maior quantidade de cavernas do Brasil. In: RASTEIRO, M. A.; MORATO, L. (orgs.) CONGRESSO BRASILEIRO DE ESPELEOLOGIA, 32, 2013. Barreiras. Anais... Campinas: SBE. p. 31-43. Disponível em: < http://www.cavernas.org.br/anais32cbe/32cbe 031-043.pdf>. Acesso em: 16 jan. 2019.

BRASIL. Lei no 9.985 de 18 de julho de 2000. Institui o Sistema Nacional de Unidades de Conservação da Natureza e dá outras providências. Disponível em: <http://www.planalto.gov.br/ccivil 03/LEIS/L9985.htm>. Acesso em: 26 fev. 2019.

BRASIL. Decreto S/N de 5 de junho de 2012. Dispõe sobre a criação do Parque Nacional da Furna Feia, nos municípios de Baraúna e Mossoró, Estado do Rio Grande do Norte. Diário Oficial [da] República Federativa do Brasil, Brasília, DF, 06 jun. 2012. Disponível em: <http://www.planalto.gov.br/ccivil 03/ Ato20112014/2012/Dsn/Dsn13320.htm>. Acesso em: 15 mar. 2019.

BRILHA, José Bernardo Rodrigues (2015). Inventory and quantitative assessment of geosites and geodiversity sites: a review. Geoheritage, v. 8, n. 2, p. 119-134.

CENTRO NACIONAL DE PESQUISA E CONSERVAÇÃO DE CAVERNAS - CECAV (2018). Base de Dados: Potencialidade de Ocorrência de Cavernas. Disponível em: <http://www.icmbio.gov.br/cecav/projetos-eatividades/potencialidade-de-ocorrencia-de-cavernas.html>. Acesso em: 21 fev. 2019.

CPRM - Serviço Geológico do Brasil (2006). Geodiversidade. Mapa Geodiversidade do Brasil Escala 1:2.500.000. Brasília: CPRM. Disponível em: <http://rigeo.cprm.gov.br/xmlui/handle/doc/10169>. Acesso em: 16 jul. 2018.

DEPARTAMENTO NACIONAL DE INFRAESTRUTURA DE TRANSPORTES - DNIT (2015). Base de Dados Shapefile. Disponível em: <http://www.dnit.gov.br/mapas-multimodais/shapefiles>. Acesso em: 23 maio. 2019.

DINIZ, M. T. M.; OLIVEIRA, G. P.; MAIA, R. P.; FERREIRA, B. (2017). Mapeamento Geomorfológico do Estado do Rio Grande do Norte. Revista Brasileira de Geomorfologia. V. 18, n. 4.

GRAY, J. M. (2004). Geodiversity: valuing and conserving abiotic nature. Londres: John Wiley \& Sons Ltd.

INSTITUTO CHICO MENDES DE CONSERVAÇÃO DA BIODIVERSIDADE (ICMBio) \& CENTRO NACIONAL DE PESQUISA E CONSERVAÇÃO DE CAVERNAS (CECAV) (2011). Projeto Karst Jandaíra: Caracterização da Sensibilidade Ambiental e Mapeamento das Cavernas de Felipe Guerra e do Sítio Espeleológico da Furna Feia e Áreas Cársticas Adjacentes. Natal $\quad$ RN. Disponível em: < http://www.icmbio.gov.br/cecav/images/stories/projetos-eatividades/Kast Jandaira/Projeto Karst Janda\%C3\%ADra - Relat\%C3\%B3rio T\%C3\%A9cnico Final.pdf>. Acesso em: 19 nov. 2018. 
INSTITUTO CHICO MENDES DE CONSERVAÇÃO DA BIODIVERSIDADE - ICMBio (2012). Delimitação shapefile do Parna Furna Feia e ZA. Disponível em: <http://www.icmbio.gov.br/portal/unidadesdeconservacao/biomasbrasileiros/caatinga/unidades-de-conservacao-caatinga/3039-parna-da-furna-feia>. Acesso em: 17 abr. 2018.

INSTITUTO NACIONAL DE PESQUISAS ESPACIAIS - INPE (2015). Imagens TOPODATA. Disponível em: <http://www.webmapit.com.br/inpe/topodata/>. Acesso em: 9 ago. 2019.

LOBO, Heros A. S; PERINOTTO, José A. J. \& BOGGIANI, Paulo C (2008). Espeleoturismo no Brasil: Panorama geral e perspectivas de sustentabilidade. Revista Brasileira de Ecoturismo. São Paulo, v.1, n.1, pp. 62-83.

LOBO, H. A. S.; VERÍSSIMO. C. U. V.; SALLUN FILHO, W.; FIGUEIREDO, L. A. V.; RASTEIRO, M. A. (2007). Potencial Geoturístico da paisagem cárstica. Global Tourism. v. 3, n. 2, nov.

MARTIN, Gabriela (2005). Pré-História do Nordeste do Brasil. 4. ed., Recife: Ed. Universitária - UFPE. p.253-275.

MEDEIROS, W. D. A. \& OLIVEIRA, F. F. G. (2011). Geodiversidade, Geopatrimóniopatrimónio e Geoturismo em Currais Novos, NE do Brasil. Mercator, Fortaleza, v. 10, n. 23, p. 59-69, set./dez.

MOREIRA, Jasmine Cardozo (2012). Interpretação ambiental, aspectos geológicos e geomorfológicos. Bol. Geogr., Maringá, v. 30, n. 2, p. 87-98.

MOURA-FÉ, M. M.; NASCIMENTO, R. L.; SOARES, L. N. (2017). Geoeducação: princípios teóricos e bases legais. XVII Simpósio Brasileiro de Geografia Física Aplicada, Campinas-SP.

PANIZZA, M. (2001). Geomorphosites: concepts, methods and examples of geomorphological survey. Chinese Science Bulettin. n.46, p.4-5.

PEREIRA, P. J. S. (2006). Património geomorfológico: conceituação, avaliação e divulgação. Aplicação ao Parque Natural de Montesinho. 2006. Tese (Doutorado em Património geológico e Geoconservação) Universidade do Minho, Escola de Ciências, Braga.

PEREIRA, Ricardo Galeno Fraga de Araújo (2010). Geoconservação e desenvolvimento sustentável na Chapada Diamantina (Bahia - Brasil). Tese (Doutorado em Geologia). Universidade do Minho, Escola de Ciências. Portugal. 2010.

PESSOA NETO, O. C.; SOARES, U. M.; SILVA, J. G. F.; ROESNER, E. H.; FLORENCIO, C. P.; SOUZA, C. A. V. (2007). Bacia Potiguar. Boletim de Geociências - PETROBRAS, Rio de Janeiro, v.15, n.2, p. 357-369.

REYNARD, E. (2005). Géomorphosites et paysages. Géomorphologie: relief, processus, environment. Paris: n. 3. P.181-188.

SANTOS, Norberto; CRAVIDÃO, Fernanda \& CUNHA, Lúcio (2010). Natureza, Paisagens Culturais e os Produtos Turísticos associados ao Território. 10.13140/RG.2.1.2605.9609.

TRAVASSOS, L.E.P.; RODRIGUES, B.D. \& TIMO, M.B (2015). Glossário conciso e ilustrado de termos cársticos e espeleológicos. Belo Horizonte: PUC Minas. 65 p.

VIEIRA, A (2014). O património geomorfológico no contexto da valorização da geodiversidade: sua evolução recente, conceitos e aplicação. Revistas Cosmos. v.7, n.1. 